Copyright (C) 2016 by Academic Publishing House Researcher

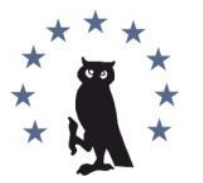

Published in the Russian Federation

European Researcher

Has been issued since 2010.

ISSN 2219-8229

E-ISSN 2224-0136

Vol. 104, Is. 3, pp. 156-167, 2016

DOI: 10.13187/er.2016.104.156

www.erjournal.ru

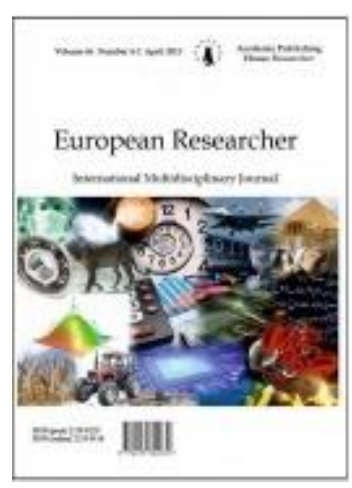

UDC 33

\title{
Relationship between Remittance and Economic Growth in Bangladesh: an Autoregressive Distributed Lag Model (ARDL)
}

\author{
${ }^{1}$ Shapan Chandra Majumder \\ ${ }^{2}$ Zhang Donghui
}

\author{
${ }^{1}$ Department of Economics, Comilla University, Bangladesh \\ PhD Candidate, School of Economics, Shandong University, P.R. China, Assistant Professor \\ E-mail: scmajumder_71@yahoo.com \\ ${ }^{2}$ School of Economics, Shandong University, P.R. China \\ PhD Supervisor, Professor of Economics, \\ E-mail:zdh@sdu.edu.cn
}

\begin{abstract}
This study examines the long-run impact of remittances on economic growth in Bangladesh. Bangladesh, being one of the top remittance-recipient countries in the world, has drawn attention to the remittance-output relationship in recent years. In 2014, remittances contributed to $8.2 \%$ of GDP of Bangladesh while the contribution was $6.7 \%$ in 2006. The main objective of this study is to investigate the impact of the remittance on economic growth (GDP). We adopted Autoregressive Distributed Lag (ARDL) models or dynamic linear regressions are widely used to examine the relationship between remittances and economic growth in the country. In testing for the unit root properties of the time series data, all variables are found stationary at first differencing level under the ADF and PP stationary tests. The study made use of diagnostic tests such as the residual normality test, heteroskedacity and serial autocorrelation tests for misspecification in order to validate the parameter estimation outcomes achieved by the estimated model. The stability test of the model is also checked by CUSUM test. The ARDL model presents that there exist a statistically significant long run positive relationship between remittance and economic growth of gross domestic product in Bangladesh.
\end{abstract}

Keywords: remittance, gross domestic product (GDP), autoregressive distributed lag (ARDL), cointegration, error correction model (ECM).

\section{Introduction}

International migration can be considered as one of the most significant factor affecting economic and sociopolitical development in the developing and developed countries in the 21st century. This could be due to the rapid increase in the volume of workers' remittances flows, and the resultant dependency on them by a number of economies to cushion external shocks, spur development, and reduce poverty levels (Paranavithana, 2014). Remittances from international migration play a significant role for a positive current account balance of Bangladesh as; the World Bank (2014) reported Bangladesh was the seven largest economy of remittance receiver (US \$ 14.22 billion) in Fiscal Year (FY) 2013-14. Remittances are conventionally defined as transfers of a 
sum of money that follow unidirectional paths from a migrant to his or her sending relatives and or friends, community, and country (Cohen 2011, Maimbo and Ratha 2005). According to new data released by the United Nations, there were 232 million international migrants (or 3.2 percent of world population) in 2013, up from 175 million in 2000. Today, remittances are recognized as one of the most important sources of global development finance. Remittance flows to developing countries are estimated to total $\$ 404$ billion in 2013, up 3.5 percent compared with 2012. Growth in remittance flows to developing countries is expected to accelerate to an annual average of 8.4 percent over the next three years, raising flows to $\$ 436$ billion in 2014 and $\$ 516$ billion in 2016 according to the latest issue of the World Bank's Migration and Development Brief (World Bank 2014). They are the second largest source, behind foreign direct investment, of external funding for developing countries and three times the size of official development assistance while supplementing the domestic incomes of millions of poor families across the world (Natacha 2012). Remittances remain a key source of external resource flows for developing countries like Bangladesh, far exceeding official development assistance and more stable than private debt and portfolio equity flows (World Bank 2014). The Global Migration Origin Database estimates that $6,832,522$ Bangladeshis live abroad, representing less than $5 \%$ of the total population and less than $10 \%$ of the total labour force. Similarly, the Bangladesh Bureau of Manpower, Employment and Training (BMET) estimates that 5.8 million Bangladeshi workers are abroad, 31\% of which are in Saudi Arabia and 24\% in the UAE (IOM; 2010).

Remittance is a significant source of external finance into Bangladesh. Remittances are now competing with the RMG industry as the largest source of foreign currency earnings for Bangladesh economy and are higher than net foreign direct investment (FDI). For example, data from the Bangladesh Central Bank show that export earnings from RMG in 2003 were estimated at US\$ 2.29 billion while net earnings from official remittances reached US $\$ 3.063$ billion (Siddiqui, 2003). Furthermore, the WB calculated that in recent years, a remittance inflow to Bangladesh has been crucial in stabilizing the current account surplus, despite a widening trade deficit (World Bank 2010). Remittance flows into developing countries have been rising over the years and of the 10 highest remittance recipient countries in 2008, six of them were developing countries; in order of remittance totals they were China, India, Mexico, Philippines, Nigeria and Bangladesh (OECD, 2009). Given the scale of remittance transfer, from a development point of view, remittances can potentially impact local livelihoods and development in the receiving countries. More interesting however, is the potential use of remittance flows for poverty reduction. Remittances alone however are unlikely to lift people out of poverty; rather, it is their interplay with other economic, social and cultural factors which determine the scale and type of impact remittances can have on poverty reduction. Thus, the focus should be on what remittances can add to the process of moving people out of poverty or reducing their vulnerability to poverty (Chimhowu et al., 2003).

The main objective of this paper is to empirically examine the relationship between remittance and its impact on economic growth in Bangladesh using the time series analysis. The study applies Autoregressive Distributed Lag (ARDL) model based on Cointegration and Granger-causality tests to determine the nature and pattern of causality between remittance and GDP growth in the country. In testing for the unit root properties of the time series data, the variables are subjected to the Augmented Dickey-Fuller (ADF). The study made use of diagnostic tests such as the residual normality test, heteroskedacity and serial autocorrelation tests for misspecification in order to validate the parameter estimation outcomes achieved by the estimated model. The stability test of the model is also checked by CUSUM test.

The rest of the study is organized as follows. Section 2 Remittances and Economic Growth in Bangladesh, Section 3 presents the Review of related Literature. Section 4 discloses the Empirical Analysis of the study. Section 5 discusses the Empirical Results while Section 6 Concludes of the study.

\section{Remittances and Economic Growth in Bangladesh}

Remittances play an important role in Bangladesh's economy, as is the case in many developing countries. According to the World Bank, Bangladesh is one of the top 10 remittance countries in the world. As seen in Table 1, total remittance inflows grew faster than GDP growth, from US $\$ 4.8$ billion in 2006 to US $\$ 14.22$ billion in 2014. Remittances as a percentage of GDP also grew, from $6.7 \%$ in 2006 to $8.2 \%$ in 2014. They also grew faster than exports of goods and services, 
increasing from $37.0 \%$ in 2005 to $50.6 \%$ in 2010 , though later declining to $43.1 \%$ in 2011. This decline is due to the fact that exports of goods and services in 2011 experienced a sudden $24.4 \%$ jump, rather than a decline in remittances. Remittances increased by a modest $6.0 \%$ in that year as shown in the table below (USAID and DFID, 2014). Saudi Arabia, the United Arab Emirates, Kuwait, the United States, and the United Kingdom are the top five country sources (in descending order) of Bangladeshi remittances; $78.2 \%$ of total remittances in 2011 originated from these countries. Bangladesh migrants to these countries account for more than $73 \%$ of the total migrants. Remittance inflows totaled US $\$ 3.3$ billion, a decline of $8.1 \%$ in the first three months of FY 2014 over the corresponding period of FY 2013, when they totaled US\$3.6 billion. Remittance inflows declined due to a large drop in out-of- country employment, especially in Middle Eastern countries. It should be noted, however, that the large and generally increasing level of personal remittances during 2005-2011 as shown in Table 1, emanating from Bangladeshi workers who have migrated abroad looking for work, serves as a red flag indicating a significant failure of the domestic economy to generate good jobs at home to employ Bangladesh's steadily growing labor force (USAID and DFID, 2014).

Table 1: Bangladesh Remittances as Percent of GDP and Export Earnings

\begin{tabular}{|c|c|c|c|c|c|c|c|c|c|}
\hline & 2006 & 2007 & 2008 & 2009 & 2010 & 2011 & 2012 & 2013 & 2014 \\
\hline $\begin{array}{l}\text { Remittances } \\
\text { (Bill.US\$) }\end{array}$ & 4.8 & 5.98 & 7.92 & 9.69 & 10.99 & 11.65 & 12.84 & 14.47 & 14.22 \\
\hline $\begin{array}{l}\text { Remittance } \quad(\% \text { of } \\
\text { GDP) }\end{array}$ & 6.7 & 7.5 & 8.6 & 9.5 & 9.5 & 9.1 & 9.6 & 9.6 & 8.2 \\
\hline Exports (\% of GDP) & 14.5 & $17 \cdot 5$ & 15.4 & 15.2 & 14.1 & 17.6 & 18 & 17.7 & 17.1 \\
\hline $\begin{array}{l}\text { Remittances } \\
\text { exports })\end{array}$ & 45.6 & 49.1 & 56.1 & 62.3 & 67.8 & 50.8 & 52.8 & 53.5 & 47.1 \\
\hline
\end{tabular}

Source: Bangladesh Economic Review, 2014.

IMF (2005) notes that the inflow of remittances on the macro-economy can lead to accelerated long-run growth as a result of additional investments in physical and human capital. According to Chami et al. (2008), remittances can increase growth by increasing investment in physical capital and human capital, and by developing the financial system in the recipient country. If there are significant financial constraints in the country that keep a large group of households from the credit market, remittances may help ease that constraint and lead to increases in the domestic investment rate. A significant portion of remittances is spent on acquiring education and nutrition, leading to a higher rate of human capital accumulation. This leads to total factor productivity and subsequent growth. In addition to the increase in higher accumulation physical and human capital, remittances can have a positive impact on growth by affecting the recipient countries' financial system. Remittances can lead to an increase in the demand for money, and expand the supply of funds in the recipient countries' banking system. This contributes to the financial development of the remittance recipient economies and subsequently causes higher economic growth. However, the effect of remittances on long-term economic growth may also be negative. For instance, inward remittances are by-products of outflows of the work force - often skilled or semi-skilled - that should negatively affect growth (World Bank 2005).

However, it is virtually argued that remittances coming by informal channels such as, hundi, relatives or friends and by self in forms of goods or cash are almost no less than that coming via formal channels. Therefore, the figure of remittance will immensely accelerate if these informal channels are controlled and, correspondingly, the legal channels are ensured.

\section{Literature Review}

There is a vast scholarship on remittances of developing, less developed (LDCs), and South Asian countries, however, studies are quite less on that of Bangladesh. As remittances are one of the most prominent ingredients of the economic growth of Bangladesh, it requires very comprehensive studies to enhance its ongoing contribution to the country. 
IMF (2005) study using time invariant instrument by applying cross-section data for 101 countries within the period ranging from 1970 to 2003, finds no statistically significant effect of remittances on economic growth. Jongwinich (2007) shows the impact of remittance on growth and also how remittance results in alleviation of poverty. He concluded that there are marginal positive effects on economic growth in Asia and Pacific countries. The findings of IMF (2005) were similarly negative but significant when measuring the impact of remittance on growth. Barguellil et al. (2013), they use panel data analysis of two groups of countries over the 1990-2006 period seems to point to the existence of a relationship between the studied variables. The first group of countries consists of the largest remittances-recipient countries in GDP percentage. The second group includes countries recipient of the largest remittances in amounts. The obtained results indicate that remittances have direct and indirect effects, only for the first group of countries. However, these effects disappear for the second group of countries.

Kyophilavong et al. (2013), they conclude that the long-run relation between remittances, financial development and economic growth are country specific, and that remittance and financial development could promote economic growth in developing countries. Therefore, policy makers in developing countries should eliminate the barriers to remittance and promote financial development in order to stimulate economic development. Bayar (2015), in his study shows that the causal relationship among the real GDP per capita growth, personal remittances received and net foreign direct inflows in the transition economies of the European during the period 1996-2013 by using causality test. He finds that there is unidirectional causality from remittances and foreign direct investment inflows to the economic growth. Shahzad et al. (2014), their research explain that Fully Modified OLS and Dynamic Ordinary Least Square estimation analysis reveal positive impact of capital, remittances, exports, and FDI on economic growth whereas a negative impact of labor on growth is observed. The causality analysis confirms the presence of long term equilibrium relation among economic growth, labor, capital, remittances, exports, and FDI. In short run, exports Granger cause growth and FDI Granger cause exports. Feedback causality is also confirmed between remittances and capital in the South Asian countries.

Adams (2009), in his study analyzes that DI is positive and significantly correlated with economic growth in both the OLS and fixed effects estimation. The study also found that FDI has an initial negative effect on DI and subsequent positive effect in later periods for the panel of countries studied. Bettin and Zazzaro (2009), in their paper they analyses the relationship between remittances and the level of financial development in economic growth. Using a panel of 66 developing countries for the period 1991-2005, authors show that an efficient banking system complements the positive effect of remittances on GDP growth. Abida and Sghaier (2014), using system Generalized Method of Moment (GMM) panel data analysis, they find strong evidence of a positive relationship between remittances and economic growth. Ramirez and Sharma (2008), using recently developed panel unit root and panel cointegration tests and the Fully Modified OLS (FMOLS) methodology in their research find that remittances have a positive and significant effect on economic growth in selected upper and lower income Latin American and Caribbean countries.

Siddique, et al. (2010), they investigate the causal link between remittances and economic growth in three countries, Bangladesh, India and Sri Lanka, by employing the Granger causality test. They find that growth in remittances does lead to economic growth in Bangladesh. In India, there seems to be no causal relationship between growth in remittances and economic growth; but in Sri Lanka, a two-way directional causality is found; namely economic growth influences growth in remittances and vice-versa. Stahl and Habib (1989) argue that there is a multiplier effect of remittances. They explain that remittances increase savings, which then increase growth. They calculated the multiplier for Bangladesh for the period of 1976-1988 to be 1.24. Mahmud (2003) as well as Siddique (2004) claims that remittances foster growth in Bangladesh. Paul and Das (2011) find a long-run positive relationship between remittances and GDP, but that there is no evidence on remittance-led growth in the short run. Ali (1981) identifies that remittances help for favorable balance of payment. On the other hand, Rahman et al. (2006) and Rahman (2009) concludes that remittance seems to have insignificant and ambiguous effects on Bangladesh's GDP. Ahmed (2010) finds that flow of remittances to Bangladesh have been statistically significant but have a negative impact on growth. 
4. Empirical Analysis of the Study

4.1 Variables, sources of data and the Model

This section sets the analytical framework used in this study by providing the model used to examine the impact of remittance on economic growth in Bangladesh from 1975-2013. This section also includes confirmation of data sources, research techniques and diagnostic tests employed in this study. This study explores the causal relationship between remittance and GDP growth in the short and long-run. In this section we estimate the impact of remittances on economic growth in Bangladesh. All the analysis of this paper has been conducted on the basis of secondary data. Most of the data are taken from World Development Indicators (WDI-2014), Economic Trends, Bangladesh Bank, Bangladesh Economic Review (Various Issues), Bangladesh Bureau of Statistics (BBS), Ministry of Foreign Affairs and Welfare, Bangladesh Association of International Recruiting Agency (BAIRA), Center for Policy Dialogue (CPD), UNCTAD and articles from reputed Journals and other sources. The study uses annual time series data from Bangladesh during 1975 -2013. All these sources of data are recognized and accepted and the provided information has been used widely in the country. So data and information of the sources incorporated in this analysis are reliable. The Augmented Dickey Fuller (ADF) unit root test is used to verify whether the variables are difference stationary.

In order to investigate the impact of remittance on GDP growth, we have specified following econometric model. The independent variables are remittance, money supply and inflation rate while the dependent variable is economic growth of GDP. The model is stated as follows:

$$
Y=f(\text { Rem, Trade, } M 2)
$$

The econometric form of the equation can be written thus:

$Y_{t}=\alpha+\beta$ Rem $_{t}+\delta M 2_{t}+$ oTrade $_{t}+U_{t}$

The linear log stochastic form of the equation can also be presented as:

$$
Y_{t}=\alpha+\beta L(\text { Rem })_{t}+\delta L(M 2)_{t}+\sigma L(\text { Trade })_{t}+U_{t}
$$

Where, $\mathrm{Y}=$ Growth Rate of Gross Domestic Product (annual \%), LRem = Remittance (Million \$US), LM2 = Money Supply (\% of GDP), LTrade = Trade (\% of GDP), $\alpha, \beta, \delta, \sigma=$ parameters to be estimated, $\mathrm{U}=$ stochastic term, $\mathrm{t}=1,2,3 \ldots 39$ (time period is from 1975- 2013) and $\mathrm{L}=$ Natural $\log$.

\subsection{ARDL model specification}

To empirically analyze the long-run relationships and dynamic interactions among the variables of interest, the model has been estimated by using the bounds testing (or autoregressive distributed lag (ARDL)) cointegration procedure, developed by Pesaran et al. (2001). The procedure is adopted for the following three reasons. Firstly, the bounds test procedure is simple. As opposed to other multivariate cointegration techniques such as Johansen and Juselius (Johansen 1988, Johansen \& Juselius 1990), it allows the cointegration relationship to be estimated by OLS once the lag order of the model is identified. Secondly, the bounds testing procedure does not require the pre-testing of the variables included in the model for unit roots unlike other techniques such as the Johansen approach. It is applicable irrespective of whether the regressors in the model are purely $I(0)$, purely $I(1)$ or mutually cointegrated. Thirdly the ARDL model is more robust and performs better for a small sample size than standard cointegration methods (Pesaran \& Shin 1999). This study uses the following ARDL model:

$\Delta Y_{t}=\theta_{1}+\sum_{i=1}^{m} \alpha_{1, i} \Delta Y_{t-i}+\sum_{i=1}^{m} \beta_{1, i} \Delta$ LRem $_{t-i}+\delta_{1} Y_{t-1}+\delta_{2}$ LRem $_{t-1}+\mu_{1, t}$

$\Delta Y_{t}=\theta_{2}+\sum_{i=1}^{m} \alpha_{2, i} \Delta Y_{t-i}+\sum_{i=1}^{m} \beta_{2, i} \Delta L M 2_{t-i}+\delta_{1} Y_{t-1}+\delta_{2} L M 2_{t-1}+\mu_{2, t}$

$\Delta Y_{t}=\theta_{3}+\sum_{i=1}^{m} \alpha_{3, i} \Delta Y_{t-i}+\sum_{i=1}^{m} \beta_{3, i} \Delta$ LTrade $_{t-i}+\delta_{1} Y_{t-1}+\delta_{2}$ LTrade $_{t-1}+\mu_{3, t}$

Where $m$ is the maximum lag length. $\delta_{i}$ are the long-run multipliers, $\theta_{i}$ are the drift and $\mu_{t}$ are white noise errors. The first step in the ARDL bounds testing approach is to estimate equation (4) to (6) by ordinary least squares (OLS) in order to test for the existence of a long-run relationship among the variables by conducting an F-test for the joint significance of the coefficients of the lagged levels of the variables, i.e., $H_{0}=\delta_{1}=\delta_{2}=0$ against the alternative

$H_{1} \neq \delta_{1} \neq \delta_{2} \neq 0$. I denote the test which normalize on $Y$ by $F_{y}(Y / \operatorname{Rem}, M 2, I R)$. Similarly, in turn we compute the F-statistics when considering the other two variables as the dependent variable. Although Pesaran et al. (2001) provide the critical values of the lower- and upper-bounds for the F-test, the lower-bound critical values are based on the fact that all of the variables are $I(0)$ 
and the upper-bound critical values are I(1). If the F-statistics exceed the upper bound; then cointegration among the variables in the LREMI exist, and the null hypothesis can be rejected. If the F-statistics are below the lower bound; then no long-run relation exists, and the null hypothesis cannot be rejected. If the $F$-statistics are within both bounds, then it is inconclusive. The approximate critical values for the $F$-statistics are obtained from Pesaran et al (2001) and Narayan (2005).

The next step is to find the optimal lag length from the estimation of the ARDL approach. The selection criteria for the optimal lags are mostly used to determine the order of the ARDL model. These criteria are the Schwarz Bayesian Criterion (SBC) and the Akaike Information Criterion (AIC). After estimating the ARDL model by the AIC or SBC criteria, the long-run relations of the variables can be estimated. With the establishment of a long-run relation, an estimation of the short-run parameters from the Error Correction Model (ECM) by using equations (7) to (9) is the next step. To ensure that the dynamics converge with the long-run equilibrium, the lagged ECM coefficient's sign must be negative and significant. The following is the formulation of a general correction model:

$$
\begin{aligned}
& \Delta Y_{t}=\theta_{1}+\sum_{i=1}^{m} \alpha_{1, i} \Delta Y_{t-i}+\sum_{i=1}^{m} \beta_{1, i} \Delta L \operatorname{Rem}_{t-i}+\vartheta_{1} E_{C C T_{t-1}}+\mu_{1, t} \\
& \Delta Y_{t}=\theta_{1}+\sum_{i=1}^{m} \alpha_{2, i} \Delta Y_{t-i}+\sum_{i=1}^{m} \beta_{2, i} \Delta L M 2_{t-i}+\vartheta_{2} E T_{t-1}+\mu_{1, t} \\
& \Delta Y_{t}=\theta_{1}+\sum_{i=1}^{m} \alpha_{3, i} \Delta Y_{t-i}+\sum_{i=1}^{m} \beta_{3, i} \Delta \text { Lrade }_{t-i}+\vartheta_{3} E C T_{t-1}+\mu_{1, t}
\end{aligned}
$$

Where $\vartheta_{i}$ which is expected to have a negative coefficient, is the speed of adjustment to equilibrium, $E C T_{t-1}$ is the coefficient for the error correction term that is obtained from the estimation of the long-run equation and $\alpha_{i}, \beta_{i}$ are the short-run dynamic coefficient model's convergence to equilibrium. To ensure that the correct statistical methods are applied to the model, we conduct diagnostic and stability tests. The diagnostic tests comprise a test for the serial correlation, function form, normality, and the heteroskedasticity (Pesaran and Pesaran 2009). In addition, Brown et al.'s (1975) stability tests, also known as the cumulative sum (CUSUM) and cumulative sum of squares (CUSUMSQ) tests based on the recursive regression residuals, are used for that purpose.

\section{5. $\quad$ Empirical Results}

5.1 Unit Root Test

ARDL framework depends on the time series characteristics and nature of the data sets. So, initially we have to examine the order of integration. This is to assure that the variables of the model are not $I(2)$ stationary to avoid spurious outcomes. As Ouattara (2004) argues that, in the presence of $I(2)$ variables the computed F-statistics provided by Pesaran et al. (2001) are not valid. Because the bound test is based on the assumption that the variables are $I(0)$ or $I(1)$. Therefore, the implementation of the unit root tests in the ARDL approach might be necessary in order to ensure that none of the variables is $I(2)$ or beyond.

For this purpose, the ADF and PP methods are used to determine the stationarity of the variables and the results are presented in Table 2(a) and Table 2(b). The results of the Augmented Dickey-Fuller (ADF) test for the stationarity of the four original series are presented in Table 2(a) and Phillips-Perron test are presented in Table 2(b). The results show that ADF and PP $t$-values for all variables are greater than critical values; therefore, the series are non-stationary. The results show that all variables are non-stationary at levels. That is, they are not integrated at order zero $I(0)$ but they became stationary after first differencing $I(1)$. The PP unit root test results as reported

\begin{tabular}{|c|c|c|c|c|c|c|}
\hline \multirow[t]{2}{*}{ Variables } & \multicolumn{2}{|c|}{ Constant and No Trend } & \multicolumn{2}{|c|}{ Constant and Trend } & \multicolumn{2}{|c|}{ No Constant \& No Trend } \\
\hline & At Level & $\begin{array}{l}\text { At } 1^{\text {st }} \\
\text { Differenced }\end{array}$ & At Level & $\begin{array}{l}\text { At } \quad 1^{\text {st }} \\
\text { Differenced }\end{array}$ & At Level & $\begin{array}{l}\text { At } \quad 1^{\mathrm{s}} \\
\text { Differenced }\end{array}$ \\
\hline $\mathrm{Y}$ & -2.248594 & -6.281999 & 06 & -6.175484 & 271 & -6.335957 \\
\hline LRem & -0.905162 & -6.344524 & $-5 \cdot 342115$ & -6.010659 & 1.600261 & -5.699389 \\
\hline
\end{tabular}
in Table 2(b) confirmed results from ADF test.

Table 2(a): ADF test for unit root 


\begin{tabular}{|lcccccc|}
\hline LM2 & 0.402284 & -7.136437 & -1.560454 & -7.332195 & 2.929546 & -5.694321 \\
\hline LTrade & -0.315910 & -8.414287 & -1.817941 & -5.957542 & 1.804965 & -7.764566 \\
\hline
\end{tabular}

Source: Author's Envies output, Note: Test Critical Value at 1 percent level.

Table 2(b): Phillips-Perron test for unit root

\begin{tabular}{|c|c|c|c|c|c|c|}
\hline \multirow[t]{2}{*}{ Variables } & \multicolumn{2}{|c|}{ Constant and No Trend } & \multicolumn{2}{|c|}{ Constant and Trend } & \multicolumn{2}{|c|}{ No Constant \& No Trend } \\
\hline & At Level & $\begin{array}{l}\text { At } 1^{\text {st }} \\
\text { Differenced }\end{array}$ & At Level & $\begin{array}{l}\text { At } \quad 1^{\text {st }} \\
\text { Differenced }\end{array}$ & At Level & $\begin{array}{l}\text { At } \quad 1^{\text {st }} \\
\text { Differenced }\end{array}$ \\
\hline $\mathrm{Y}$ & -6.822525 & -40.27035 & -10.25375 & -36.39530 & -1.120999 & -28.37128 \\
\hline LRem & -1.852234 & -2.555432 & -2.416747 & -1.968226 & -1.428871 & -2.629873 \\
\hline LM2 & 0.835886 & -7.156782 & -1.459843 & -8.258181 & 4.405306 & -5.755419 \\
\hline LTrade & -0.315910 & -8.414287 & -1.662439 & -12.03302 & 2.577353 & -7.604816 \\
\hline
\end{tabular}

Source: Author's Envies output, Note: Test Critical Value at 1 percent level.

\subsection{Bound Tests for Cointegration}

Table 3 reports the results of the ADRL bounds cointegration tests. It shows the calculated F-statistic when the regression is normalized on the economic growth. The search for cointegrating relations has been restricted to growth variable as the dependent variable based on the fact that the study strictly utilized a growth regression model. The computed $F$-statistic (8.137967) is higher than the upper critical bound at $1 \%, 5 \%$ and $10 \%$ critical values as indicated in Table 3 . This provided evidence to reject the null hypothesis of no cointegration at $1 \%, 5 \%$ and10\% significance level for the growth model. It can therefore be concluded from the ARDL bounds test that there is a long-run relationship among the variables. Following the establishment of long-run cointegration relationship among the variables, the long-run and short-run dynamic parameters for the variables are obtained. The empirical results of the long-run model are presented in Table 4, while the results of the error correction model are presented in Table 5 .

Table 3: ARDL Bounds test for Cointegration

\begin{tabular}{|c|c|c|c|c|c|}
\hline \multicolumn{3}{|l|}{ Model } & \multicolumn{3}{|c|}{ F-statistics using lag 3} \\
\hline \multicolumn{3}{|c|}{ F(Y, LRem, LM2, LTrade) } & \multicolumn{3}{|l|}{$8.137967^{* * *}$} \\
\hline \multicolumn{3}{|c|}{ Pesaran, et at.(2001) } & \multicolumn{3}{|l|}{ Narayan (2005) } \\
\hline Critical Value & $\begin{array}{l}\text { Lower Bound } \\
\text { Value }\end{array}$ & $\begin{array}{l}\text { Upper Bound } \\
\text { Value }\end{array}$ & $\begin{array}{l}\text { Lower Bound } \\
\text { Value }\end{array}$ & $\begin{array}{l}\text { Upper } \\
\text { Value }\end{array}$ & Bound \\
\hline 1 percent & 3.74 & 5.06 & 4.768 & 6.670 & \\
\hline 5 percent & 2.86 & 4.01 & $3 \cdot 354$ & 4.774 & \\
\hline 10 percent & 2.45 & 3.52 & 2.752 & 3.994 & \\
\hline
\end{tabular}

Critical values are obtained from Pesaran et al. (2001), Table CI(iii) Case III: Unrestricted intercept and no trend, p. 300. Critical values are obtained from Narayan (2005), Table case III: unrestricted intercept and no trend, p. 10. ${ }^{*},{ }^{*}$ and $* *$ indicate significance at $10 \%, 5 \%$ and $1 \%$ levels, respectively.

Table 4: Estimated ARDL Long-Run Coefficients

\begin{tabular}{|l|l|l|l|l|}
\hline Variable & Coefficient & Std. Error & t-Statistic & Prob. \\
\hline \hline $\mathrm{C}$ & 2.332246 & 1.266597 & 1.841349 & 0.0821 \\
\hline $\mathrm{D}(\mathrm{Y}(-1))$ & 0.661304 & 0.311043 & 2.126084 & 0.0476 \\
\hline $\mathrm{D}(\mathrm{Y}(-2))$ & 0.437727 & 0.248298 & 1.762914 & 0.0949 \\
\hline $\mathrm{D}(\mathrm{Y}(-3))$ & 0.385827 & 0.119657 & 3.224448 & 0.0047 \\
\hline $\mathrm{D}($ LREM(-1)) & -0.000917 & 0.000821 & -1.117333 & 0.2785 \\
\hline $\mathrm{D}($ LREM(-2)) & 0.000135 & 0.001003 & 0.134767 & 0.8943 \\
\hline
\end{tabular}




\begin{tabular}{|l|l|l|l|l|}
\hline D(LREM(-3)) & $6.26 \mathrm{E}-05$ & 0.000940 & 0.066593 & 0.9476 \\
\hline D(LM2(-1)) & -0.147704 & 0.064468 & -2.291122 & 0.0342 \\
\hline D(LM2(-2)) & -0.123919 & 0.068429 & -1.810897 & 0.0869 \\
\hline D(LM2(-3)) & -0.098145 & 0.057452 & -1.708301 & 0.1048 \\
\hline D(LTRADE(-1)) & -0.047723 & 0.090877 & -0.525135 & 0.6059 \\
\hline D(LTRADE(-2)) & -0.013440 & 0.095223 & -0.141142 & 0.8893 \\
\hline D(LTRADE(-3)) & -0.014996 & 0.078170 & -0.191832 & 0.8500 \\
\hline Y(-1) & -1.880399 & 0.410062 & -4.585641 & 0.0002 \\
\hline LREM(-1) & -0.000347 & 0.000155 & -2.237009 & 0.0382 \\
\hline LM2(-1) & 0.146611 & 0.039845 & 3.679497 & 0.0017 \\
\hline LTRADE(-1) & 0.115842 & 0.066011 & 1.754888 & 0.0963 \\
\hline \hline R-squared & 0.818361 & Mean dependent var & -0.029817 \\
\hline Adjusted R-squared & 0.656904 & S.D. dependent var & 1.457674 \\
\hline S.E. of regression & 0.853823 & Akaike info criterion & 2.828267 \\
\hline Sum squared resid & 13.12225 & Schwarz criterion & 3.583722 \\
\hline Log likelihood & -32.49467 & Hannan-Quinn criter. & 3.089050 \\
\hline F-statistic & 5.068608 & \multicolumn{5}{|l|}{ Durbin-Watson stat } & 2.172998 \\
\hline Prob(F-statistic) & 0.000712 & \multicolumn{4}{|l}{} \\
\hline
\end{tabular}

Table 5 gives the results of the short-run dynamic coefficients associated with the long-run relationships obtained from the ECM equation. The error correction terms in the models are highly significant and correctly signed. This indicates adjustment to long-term equilibrium in the dynamic model. The coefficients of error correction term are (-1.644635). This implies that deviations from the remittance to economic growth adjust quickly. To ensure the fitness of the model, specification problems associated with serial correlation, normality and heteroskedasticity are checked with diagnostics tests, including the test for serial correlation (LM test), heteroskedasticity, and normality (JB (N)). The results are presented in table 6 below. Pesaran and Pesaran (1977) suggest using Brown et al. (1975) stability test. This technique is also known as cumulative (CUSUM) and cumulative sum of squares (CUSUMSQ). The CUSUM and CUSUMSQ statistics are updated recursively and plotted against the break points. If the plots of CUSUM and CUSUMSQ statistics stay in the critical bounds of 5 percent level of significance, the null hypothesis of all coefficients is the given regression are stable cannot be rejected.

Table 5: Error Correction Representation for the Selected ARDL Model

\begin{tabular}{|l|l|l|l|l|}
\hline Variable & Coefficient & Std. Error & t-Statistic & Prob. \\
\hline $\mathrm{D}(\mathrm{Y}(-1))$ & 0.538902 & 0.221557 & 2.432347 & 0.0236 \\
\hline $\mathrm{D}(\mathrm{Y}(-2))$ & 0.391989 & 0.202676 & 1.934062 & 0.0661 \\
\hline $\mathrm{D}(\mathrm{Y}(-3))$ & 0.401848 & 0.113875 & 3.528858 & 0.0019 \\
\hline $\mathrm{D}($ LREM(-1)) & $-5.37 \mathrm{E}-05$ & 0.000755 & -0.071132 & 0.9439 \\
\hline $\mathrm{D}($ LREM(-2)) & -0.000158 & 0.000935 & -0.169458 & 0.8670 \\
\hline $\mathrm{D}($ LREM(-3)) & 0.000534 & 0.000686 & 0.778188 & 0.4447 \\
\hline $\mathrm{D}(\mathrm{LM} 2(-1))$ & -0.111814 & 0.050361 & -2.220259 & 0.0370 \\
\hline $\mathrm{D}($ LM2(-2)) & -0.035606 & 0.050017 & -0.711865 & 0.4840 \\
\hline $\mathrm{D}($ LM2(-3)) & -0.026222 & 0.046932 & -0.558723 & 0.5820 \\
\hline $\mathrm{D}($ LTRADE(-1)) & 0.019966 & 0.067709 & 0.294872 & 0.7709 \\
\hline D(LTRADE(-2)) & 0.020165 & 0.076189 & 0.264673 & 0.7937 \\
\hline D(LTRADE(-3)) & 0.068822 & 0.064496 & 1.067069 & 0.2975 \\
\hline ECT(-1) & -1.644635 & 0.281171 & -5.849231 & 0.0000 \\
\hline R-squared & 0.794598 & \multicolumn{2}{|c|}{ Mean dependent var } & -0.029817 \\
\hline Adjusted R-squared & 0.682561 & \multicolumn{2}{|l}{ S.D. dependent var } & 1.457674 \\
\hline
\end{tabular}




\begin{tabular}{|l|l|l|l|}
\hline S.E. of regression & 0.821278 & Akaike info criterion & 2.722642 \\
\hline Sum squared resid & 14.83896 & Schwarz criterion & 3.300343 \\
\hline Log likelihood & -34.64624 & Hannan-Quinn criter. & 2.922065 \\
\hline Durbin-Watson stat & 2.246969 & & \\
\hline
\end{tabular}

Table 5 indicates the underlying ARDL equation passes the diagnostic tests. The stability of the long-run coefficients, along with the short run dynamics of the estimated ARDL model are confirmed with the test of CUSUM and CUSUMSQ. As can be seen in Figure 1, the plot remains within critical bounds at $5 \%$ significance, accepting the null hypothesis that all coefficients and the ECM are stable.

Table 6: ARDL - VECM Model Diagnostic tests

\begin{tabular}{|ll|}
\hline Test Statistic & LM $\left(\chi^{2}\right)$ \\
\hline Serial Correlation & 0.7101 \\
\hline Normality & 0.462708 \\
\hline Heteroskedasticity & 0.5084 \\
\hline
\end{tabular}

Source: Author's Envies output

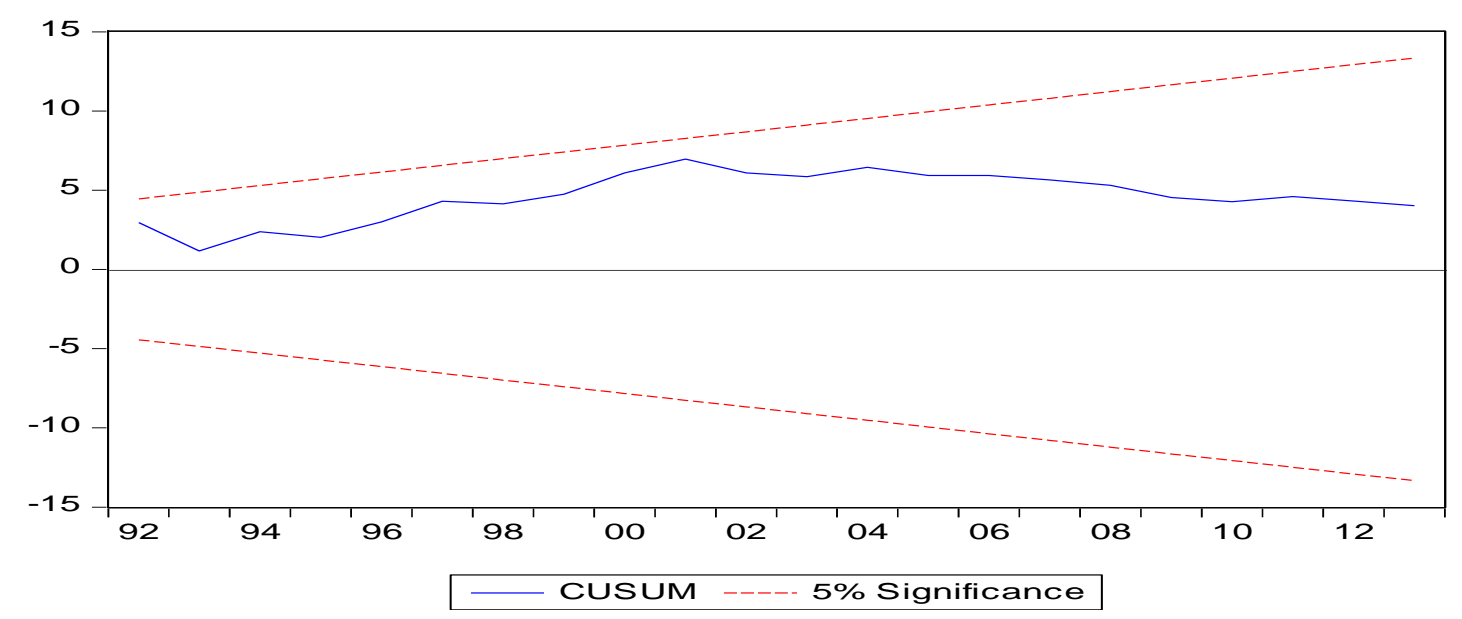

Figure 1: Stability Test (CUSUM Test)

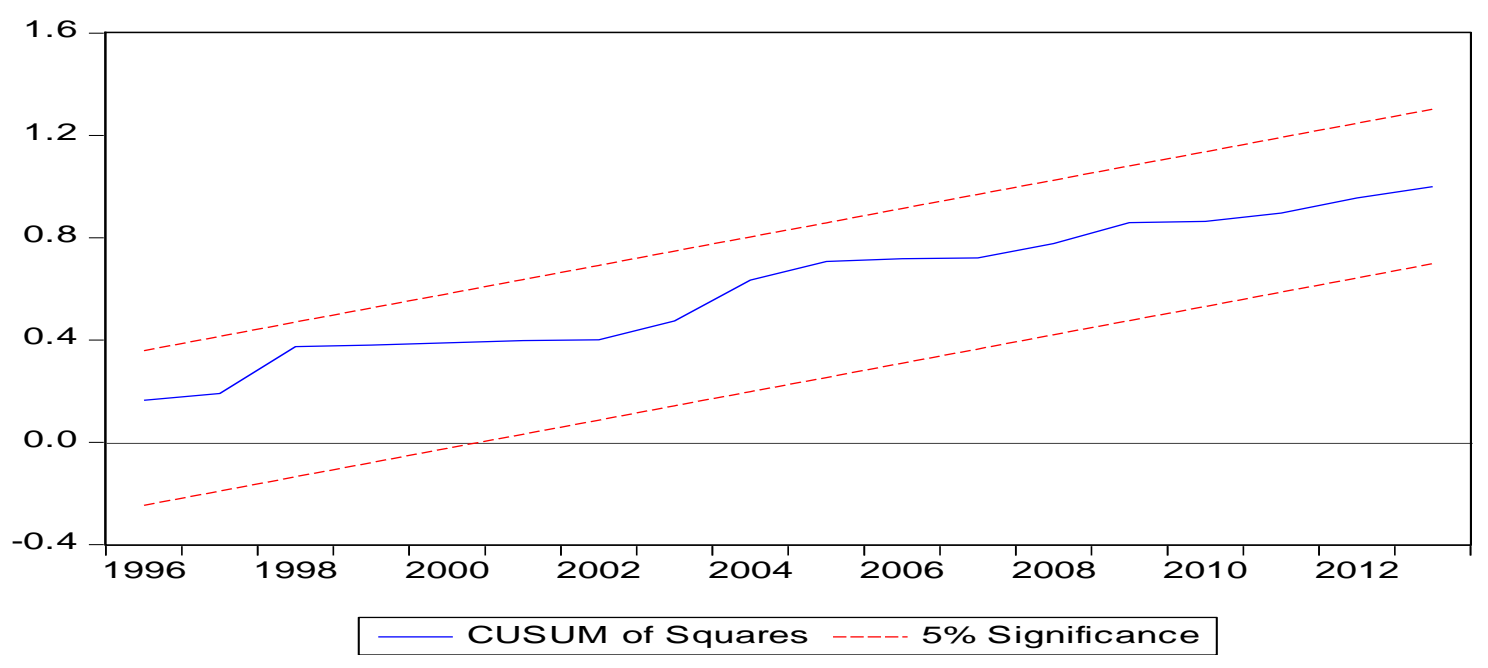

Figure 2: Stability Test (CUSUMSQ Test) 


\section{Conclusion}

This study has examined the impact of remittances, trade and money supply on economic growth of Bangladesh, using time series data from 1975-2013 by employing Bounds testing approach. Bounds test suggested that the remittances have only the long-run positive relationship with economic growth of Bangladesh. The model having lag 3 is the best model and because it has no serial correlation, no heteroskedasticity and the residuals are normally distributed. The model is also stable. The model has getting towards long-run equilibrium at the speed of 1.644635 . The model has no short-run causality from independent variables to dependent variable. It has long-run association among the variables and they move together. The error correction terms in the models are highly significant and correctly signed. This indicates adjustment to long-term equilibrium in the dynamic model. The coefficients of error correction term are (-1.644635). This implies that deviations from the remittance to economic growth adjust quickly. Faini $(2002,2003)$ also finds a positive relationship between growth and remittances using cross-country data.

\section{References:}

1. Abida, Z., and Sghaier, I. M., (2014). Remittances, Financial Development and Economic Growth: The Case of North African Countries. The Romanian Economic Journal, Volume- XVII no. 51, 137-170.

2. Adams, S. (2009). Foreign Direct investment, domestic investment, and economic growth in Sub-Saharan Africa. Journal of Policy Modeling, 31(6), 939-949.

3. Ahmed, M. S., (2010). Migrant Workers Remittance and Economic Growth: Evidence from Bangladesh. ASA University Review, Vol. 4 No. 1 (January-June), pp. 1-13;

4. Ali, S. A. (1981). An Analysis of the Institute of Home Remittance by Bangladeshi Workers Abroad on the National Economy in Labor Migration from Bangladesh to Middle East. Washington, DC: World Bank, World Bank Staff Working Paper, No. 454.

5. Barguellil, A., Zaiem, M. H., and Zmami, M., (2013). Remittances, Education and Economic Growth A Panel Data Analysis. Journal of Business Studies Quarterly, Volume 4, Number 3, 129-139.

6. Bayar, Y., (2015). Impact of Remittances on the Economic Growth in the Transitional Economies of the European Union. Economic Insights - Trends and Challenges, Vol.IV(LXVII) No. 3, 1-10. http://www.upg-bulletin-se.ro/archive/2015-3/1.Bayar.pdf

7. Bettin, G., and Zazzaro, A., (2009). Remittances and Financial Development: Substitutes or Complements in Economic Growth? Money \& Finance Research Group, Hamburg, Germany. Working Paper, No-28.

http://docs.dises.univpm.it/web/quaderni/pdfmofir/Mofiro28.pdf

8. Brown R.L., J. Durbin, and J. M. Evans (1975). Techniques for testing the constancy of regression relationship over time. Journal of Royal Statistical Society,B37: 149-1491.

9. Chimhowu, A., Piesse, J., and Pinder, C., (2003). Assessing the Impact of Migrant Workers Remittances on Poverty', paper presented at the EDIAS Conference on New Directions in Impact Assessment for Development: Methods and Practice, 24-25 November, Institute of Development Policy and Management, University of Manchester, UK.

10. Cohen, J. H. (2011). Migration, Remittances, and Household Strategies. In Annual Review of Anthropology, 40: 103-114.

11. Faini R (2002). Development, Trade, and Migration. Revue d'Économie et du Développement. Proceedings from the ABCDE Europe Conference, 1-2, pp. 85-116.

12. Faini, R., (2003). The Brain Drain: An Unmitigated Blessing? Centro Studi Luca d'Agliano Development Studies Working Paper No. 173.

13. IMF (2005). World Economic Outlook, International Monetary Fund, Washington DC.

14. International Monetary Fund. (2005). Two Current Issues Facing Developing Countries. In World Economic Outlook: Globalization and External Imbalances. Washington D.C.: World Economic and Financial Surveys.

15. International Organization for Migration, (2010). Migration Remittances and Assets in Bangladesh.

16. Johansen, S. and Juselius, K., (1990). Maximum likelihood estimation and inference on cointegration-with application to the demand for money. Oxford Bull. Econ. Stat., 52: 169-210. 
17. Jongwanich, J., (2007). Worker's Remittances, Economic Growth and Poverty in Developing Asia and Pacific Countries: UNESCAP Working Paper 07/o1. Bangkok, Thailand: Economic and Social Commission for Asia and Pacific.

18. Kyophilavong, P., Uddin, G. S., and Sjo, B., (2013). An examination of the remittance, financial development, and economic growth in developing countries. Journal of Economic and Financial Modelling, Vol.1 (1), pp.47-55.

19. Mahmud, Wahiduddin (2003). Bangladesh: Development Outcomes and Challenges in the Context of Globalization. Conference on the Future of Globalization at Yale University (Oct 1011); available at: www.ycsg.yale.edu/activities/files/Wahid.doc.

20. Maimbo, S. M. and D. Ratha, eds. (2005). Remittances. Development Impact and Future Prospects. Washington: The World Bank.

21. Narayan, P. K., (2005). The saving and investment nexus for China: evidence from cointegration tests. Applied Economics, 37, 1979-1990.

22. Natacha, S., (2012). Remittances and Moral Economies of Bangladeshi New York Immigrants in Light of the Economic Crisis. Graduate School of Arts and Sciences, COLUMBIA UNIVERSITY.

23. OECD. (2009). International Migration Outlook, Organisation for Economic Cooperation and Development, Paris.

24. Paranavithana, H., (2014). Do Workers' Remittances Cushion Economic Growth in Sri Lanka? International Journal of Business and Social Science, Vol. 5, No. 10(1), 44-56.

25. Paul, B. P. and Das, A., (2011). The Remittance-GDP Relationship in the Liberalized Regime of Bangladesh: Cointegration and Innovation Accounting. Theoretical and Applied Economics, Vol. 18, No. 9 (September), pp. 41-60; available at: http://store.ectap.ro/articole/636.pdf.

26. Pesaran, M. H. and Y. Shin (1999). An autoregressive distributed lag modelling approach to cointegration analysis. In Strom, S. (ed.), Econometrics and Economic Theory in the 2oth Century: The Ragnar Frisch Centennial Symposium. Chapter 11. Cambridge: Cambridge University Press.

27. Pesaran, M.H., Y. Shin and R.J. Smith, (2001). Bounds testing approaches to the analysis of level relationships. Journal of Applied Economics., 16: 289-326.

28. Pesaran, M.H. and B. Pesaran (2009). Time Series Econometrics: using Microfit 5.O. Oxford: Oxford University Press.

29. Rahman, M. (2009). Contribution of Exports, FDI, and Expatriates' Remittances to Real GDP of Bangladesh, India, Pakistan and Sri Lanka. Southwestern Economic Review, Vol. 36, pp. 141-153;

30. Rahman, M., Mustafa, M., Islam, M., and Guru-Gharana, K. K., (2006). Growth and Employment Empirics of Bangladesh. Journal of Developing Areas, Vol. 40, No. 1, pp. 99-114.

31. Ramirez, M. D., and Sharma, H., (2008). Remittances and Growth in Latin America: A Panel Unit Root and Panel Cointegration Analysis. Economics Department, Yale University, Working Paper No. 51.

32. Shahzad, S. J. H., Ali, S., Rehman, M.U., and Abbasi, F., (2014). Relationship between Remittance, Export, Foreign Direct Investment and Growth in South Asia: A Panel Cointegration and Causality Analysis. MPRA Paper No- 65355, University Library of Munich, Germany.

https://mpra.ub.uni-muenchen.de/65355/1/MPRA_paper_65355.pdf

33. Siddiqui, T. and Abrar, C. R. (2003). Migrant Worker Remittances and Micro-Finance in Bangladesh. Working Paper No. 38, Social Finance Programme, International Labour Office (ILO).

34. Siddique, T., (2004). Efficiency of Migrant Workers' Remittances: The Bangladesh Case. Manila, The Philippines: Asian Development Bank .

35. Siddique, A., Selvanathan, E. A., and Selvanathan, S. (2010). Remittances and Economic Growth: Empirical Evidence from Bangladesh, India and Sri Lanka, Discussion Study, University of Western Australia, No. 10.27.

36. Stah, Charles W. and Ahsanul Habib (1989). The Impact of Overseas Workers' Remittances on Indigenous Industries: Evidence from Bangladesh. The Developing Economies, Vol. 27, pp. 269-285. 
37. USAID and DFID Inclusive Growth Diagnostic Team - Bangladesh, (2014). BANGLADESH Inclusive Growth Diagnostic.

38. World Bank. (2012). Bangladesh: Towards Accelerated, Inclusive and Sustainable Growth - Opportunities and Challenges. (in Two Volumes) Volume II: Main Report. Poverty Reduction and Economic Management Sector Unit, South Asia Region, World Bank.

УДК 33

\title{
Взаимосвязь между денежными переводами и экономическим ростом в Бангладеше: авторегрессионная модель распределенных лагов (ARDL)
}

\author{
${ }^{1}$ Шапан Хандраа Маджумдер \\ 2 Джанг Донгхай
}

\author{
${ }^{1}$ Comilla University, Bangladesh \\ $\mathrm{PhD}$, доцент \\ E-mail: scmajumder_71@yahoo.com \\ ${ }^{2}$ School of Economics, Shandong University, P.R. China \\ $\mathrm{PhD}$, професcop \\ E-mail: zdh@sdu.edu.cn
}

Аннотация. Данное исследование рассматривает долгосрочное влияние денежных переводов на экономический рост в Бангладеше. Бангладеш, являясь одной из лучших стран - реципиентов переводов в мире, обратил внимание на remittance-output в последние годы. В 2014 году денежные переводы способствовали увеличению ВВП на 8,2 \%. В 2006 г. этот показатель находился на уровне 6,7 \%. Основная цель настоящей работы - исследовать влияние денежных переводов на экономический рост (ВВП). Авторы использовали авторегрессионную модель распределенных лагов (ARDL) или динамическую линейную регрессию, широко применяемую для изучения взаимосвязи между денежными переводами и экономическим ростом в стране. ARDL модель показывает, что существует статистически значимая долгосрочная перспектива положительной связи между денежными переводами и экономическим ростом валового внутреннего продукта в Бангладеше.

Ключевые слова: денежные переводы, валовый внутренний продукт (ВВП), авторегрессия распределенным лагом (ARDL), коинтеграция, модель коррекции ошибок (ECM). 